\title{
UTILIZING STORYTELLING TECHNIQUE USING FINGER PUPPET IN TEACHING VOCABULARY MASTERY TO YOUNG LEARNES
}

\author{
by: \\ Ira Riyani \\ Suryakancana University \\ Irariyani09@gmail.com
}

\begin{abstract}
Vocabulary is one of the most important things to teach English to young learners, however in the practice it faced some issues especially on the use of medias, the use of media which is not interesting can make students' easy to get bored in learning. This research paper is intended at increasing vocabulary mastery and describing the implementation of teaching vocabulary by using storytelling to teach vocabulary to the fifth grader students of Jamaras elementary school. This research focused to get insight on the implementation of storytelling by using finger puppet in teaching vocabulary to young learners, to find out the strength and weaknesses of teaching vocabulary through story telling using finger puppet, and to find out the students response in teaching vocabulary through storytelling using finger puppet. This study employed a qualitative design. The researcher used two narrative stories to gather the data. Concerning the qualitative data, this research collected and analyzed data from classroom observation, guided interview, and guided questionnaire. This research was conducted in elementary school in Cianjur, involving a teacher and students of Jamaras elementary school. The participants were ten students of the fifth grade. The findings show, that storytelling by using finger puppet is beneficial to teach vocabulary, because it made the student easy to get new vocabulary. Whereas the strengths of the use of storytelling using puppet in teaching vocabulary were the students were more interested and not bored in the learning process. The weaknesses of the use of implementation storytelling using puppet was the students more focus on puppet than on the story that conveyed by the teacher and also from the students response from the questionnaire teaching vocabulary through storytelling can help them to get the new vocabulary in a fun way.
\end{abstract}

Keyword: Storytelling, finger puppet, vocabulary, young learners. 


\section{INTRODUCTION}

The children have their own characteristics, which are different from adults. The characteristics cover their ways of thinking, their attitude, their aptitude, et cetera. Brumfit (1997, p. 5) gives a list of the characteristics which young learners share: Young learners are only just beginning their schooling, so that teachers have a major opportunity to mould their expectations of life in school, as a group they are potentially more differentiated than secondary or adult learners, for they are closer to their varied home cultures, and new to the conformity increasingly imposed across cultural grouping by the school.

Their learning can be closely linked with their development of ideas and concepts because it is so close to their initial experiences of formal schooling. Cameron (2003) argues that the continuing growth of teaching English to young learners brings a number of challenges. Starting to learn English at an earlier age may not bring automatic improvements to proficiency levels unless teacher education and second language teaching both adapt to meet the challenges of the new situation.

In language learning context it is believed that children will learn a foreign language more effectively under certain conditions. Therefore, there are some assumptions about language learning that should be considered when teaching English as a foreign language to children.Children love being read stories, and most of the vocabulary for a story can be pre-learned through games before the story is read. Telling a story in a foreign language is one of the simplest and richest sources of input for children as long as there are lots of colorful pictures the children can look at while listening. Storytelling is a method to tell a story to the listeners, either in the form of words, pictures, images, and sounds.

Storytelling is often used in teaching and learning primarily at the beginner level, middle, or children. Storytelling is very helpful for the teacher to teach the student to get many vocabularies. And the writer will use puppet as media to deliver the story. Puppets are objects used in theatrical performances. They are similar to dolls. They usually use strings or other things to make the puppet move and to look alive. So that when learning the child will not feel bored and will 
increase the interest of children in learning. Thus, the use of storytelling using puppet as the media in teaching vocabulary is significant.

\section{THEORETICAL FRAMEWORKS}

Storytelling is a form of communication that predates written human history as a means of teaching lessons and passing history down from one generation to another (Cited by Eck 2006, p. 10).In other hand, Moeslichatoen (1999, p.157), "Story telling is a practical and powerful teaching tool especially for language learning".

\section{Storytelling Models}

Morgan and Dennehy (1997) assert that components of an effective story embrace five sequential components:

1) The setting: a description of the time, place, characters and context so you provide something the audience can mentally image and feel a part of.

2) Build up: a sequence of events that warns the listener that something (usually some type of conflict) is about to happen. This creates suspense, interest and attention.

3) Crisis: the climax or high point of the story. This is also the place to introduce a new element and/or a turning point

4) Learning: point out what the central characters learned. Here lies the lesson of the story

5) How change ensued in the characters behaviors, awareness, abilities: the storyteller focuses on the learning to be retained by the listener and is cautioned to not assume that the listener always understands the lesson of the story.

\section{Storytelling in Teaching Vocabulary}

Coady and Huckin (1997, p.5) state that in recent years, second language vocabulary acquisition has become an increasingly interesting topic ofdiscussion for researchers, teachers, curriculum, designers, theorists, and others involved in second language 
learning. Lewis (1997, p.44) states that the most efficient language and learning must be based on the real nature of both language and learning. In Elementary School, vocabulary is the first step to learn English, because without knowing a lot of vocabulary in English the children will get difficulties in mastering the language skills. To teach vocabulary in Elementary School, especially for children, is not easy. Teaching children is different from teaching adults. We must have extra power to teach them, because the children have certain characteristics andneed treatment. So we must give the basic vocabulary to them to make them understand English.

\section{The Benefits of Storytelling}

Rose and Nicholl (1997) the vivid images stimulated by storytelling promote character identification thus engaging the student as an active participant in the learning process.In addition, Pellowski (1991, p.15) illustrates the major points of the importance of storytelling as follows:

1) It grows from the playful elements of human nature and satisfies a need for self - entertainment.

2) It can be used to clarify the environments around us since we are humans, we need to make sense of things in order to find the reason behind evolution.

3) It is used as a means to explain the supernatural forces which are believed to be found in the world at that time in order to satisfy religious beliefs.

4) It can achieve an aesthetic need for beauty, form and regularity through expressive music and language.

\section{Definition of Puppet}

Lepley (2001) mentions that puppetry is a medium for students to use to express themselves and begin to explore the various components of the English language. So puppet is an inanimate figure that is made to move by human effort before an audience.

\section{The Types of Puppet}

There are some kind of puppet presented by Yellen, Blake and DeVries 
(2004):

1) Sock puppet which are demonstrated by placing fingers in the toe and the thumb in the heel. The puppet comes alive by opening and closing the hand. The sock is added by cloth, felt buttons, beads, etc.

2) Finger puppets which are made of old glove. On each finger, draw, color, or paint facial features of different characters and add bits of yarn, sequins, or buttons. Each finger should contain a face with a different expression or look.

3) Paper-bag puppets which are made of the paper bag. Large bags can be placed over children's heads and worn as full masks. Holes for eyes, nose, and mouth can be cut and the bags decorated with crayons or other materials. Smaller paper bags lend themselves as hand puppets.

4) Stick and ball puppets. Which are made of modern dowel, tongue depressor, or beat coat hanger plus a plastic foam ball or old tennis ball.

5) Shadow puppets which are made of stiff cardboard.

\section{How to Use Puppet in Teaching}

According to Garland (2013), there are six activities of using puppet in teaching:

1) Question Time, ask a child to come to the front of the class to ask the puppet questions such as "What is your name?", "how old are you?" and so on. The puppet can then response and ask the child the same question.

2) Mind Reading, ask a child to come to the front of the classroom and think of a word or phrase that the puppet is thinking, linked to what they've learned that day. The other children must ask questions to guess what the puppet is thinking.

3) Story Time, the puppet could sit on your knee when you're reading a story to your class. It can help to emphasize key points in the story with exaggerated movements. It could also be your assistant - turning the page or passing props, for example.

4) Read with Me, reading to a puppet is a good way for shy or less confident children to practice reading out loud. For those who are not yet able to read words, they can use picture clues to tell the story to their puppet instead. 
5) Puppet Postcards, if the puppet goes away to somewhere exciting, they can send the children a postcard.

6) Writing to the Puppet, the children can use the puppet to practice writing in the target language. Maybe they could send the puppet a birthday card, or invite him or her to the school's International Day or summer fete.

\section{Vocabulary}

Hornby (2006, p. 1645) vocabulary is all the words that a person knows or uses and it is all the words in a particular language. In other hand, Jackson and Amvela (2000, p. 11) say that the terms vocabulary, lexis, and lexicon are synonymous.

\section{The Importance of Vocabulary}

Richards (2002, p.255), vocabulary is the core component of language proficiency and provides much of the basis for how well learners speak, listen, read, and write. In addition, Richards (2002, p. 580) state that vocabulary is a set of lexeme, including single words, compound words, and idioms.

\section{The Aspect of Vocabulary}

There are some aspects in learning vocabulary. According to Lado (2003), there are some vocabulary aspects as follows:

a. Meaning, when the teacher delivering the students about the meaning, the teacher should explain that a word may have more than one meaning when it used in different context. In order to discover the meaning, the teacher can use ways such as guided discovery and using dictionaries

b. Spelling, in learning vocabulary, spelling is important because it aids in reading and as the connector of letters and sounds. Spelling there may be different acceptable written forms for the same word within the same variety of English, due to the fact that they belong to different varieties as happens with many 
British or American English terms (Nations, 1997, p. 51 as cited in Kareem, 2000, p. 6).

c. Pronunciation, pronunciation is the way in which a particular person pronounces the words of language (Hornby, 2005, p.1164). Most of words have only one pronunciation, but sometimes a word has two or more pronunciations. The students want to able to speak English well with understandable pronunciation. So that they can communicate without annoyance and it makes receiver easier to communicate.

d. Word Classes,word classes are categories of word. According to Hatch and Brown (1995, p.218) the word classification in based on their functional categories which are called part of speech. There are parts of speech should be practiced fluently to the students such as nouns, verbs, adjectives, adverbs, pronouns, preposition, conjunctions, and interjections.

\section{Teaching Vocabulary}

According to Jackson (2002) these two kinds of vocabularies, are elaborated as the following:

1) Active vocabulary, the active vocabulary is the words that the students use in their own speech and writing. It is used in oral or written expression by the students.

2) Passive vocabulary, the passive vocabulary is the words that the students recognize and can make senses of in the speech or writing of other people. It means the words that the students recognize and understand when they occur in a context, or students need someone to say something that helps them recall the word meanings.

\section{Definition of Young Learner}

Young learners are generally display an enthusiasm for learning and a curiosity about the world around them (Harmer, 2008, p. 82).

\section{The Characteristics of Young Lerner}


According to Kasihani (2007, p.15) the characteristics of young learner are as follows:

a. They have egocentric attitude. It means that the young learner like to connect the lesson with their environment.

b. They are difficult to differentiate between abstract and concrete things.

c. They tend to imaginative and more active. It means that the young learner like the lesson by conducting the game.

d. The young learner is easy to get bored. It means that their concentration is shorter than the adult leaner.

\section{How to Teach English to Young Learner}

Teaching methods and learning materials given to students must be enjoyable and interesting in order to maintain their interest in learning. The followings are the elaboration regarding to some points to be considered in teaching English to young learners. According to Pinter (2006) that young learners have a great curiosity to try new things and to explore concrete to abstract things.

\section{METHOD}

This part focuses on the process of conducting the research. These include research design, data collection, and data analysis. This research employed a descriptive qualitative that can maintain close association with both participants and activities within the setting. Alwasilah (2009, p. 143) stated that qualitative study focuses on the issue of particular phenomena which has internal validity and contextual understanding rather than generalibility and comparability. In addition Bodgan and Taylor (1975, P.5) argue that "qualitative research is research procedure that produce descriptive data, such as written or spoken from human and their behaviors who can be observe, cited in Setiyadi (2006, p. 219).

The participants of this research involved 40 students of SDN Jamaras Elementary School at fifth grade consist of 25 girls and15 boys. For the sample of the research, the researchers chose ten participants including five girls and five boys. It was done because there is a limitation to a number of the participants regarding to the time efficiency in analyzing the data obtained. 


\section{FINDINGS AND DISCUSSION}

\section{a. Discussion of the Implementation in Teaching Vocabulary by Storytelling}

The first meeting of observation that was conducted on $16^{\text {th }}$ of July 2018 . As usual, the teacher began the class by discussing the main material in the certain chapter which will be learned. Then, the teacher asked the students using English. But the response of students is still low, because they do not know the meaning of the teacher's questions.

The second as the last observation in class was conducted on $17^{\text {th }}$ of July 2018 in Jamaras Elementary School. As usual, the teacher greets the students with greetings. But there is little change, that is when the teacher asked to use English students also respons with English. Students become brave in speaking in foreign languages in front of the crowd. After which the teacher leads the prayer, then she reviewed the material presented at the end of the meeting. After that, the teacher tells about what material will be spoken on that day, unexpectedly very good student response, some students look enthusiastic when the teacher informed about the lesson to be discussed.

From the result of the observation and interview above, it was found that at the first the students' ability in vocabulary was still low. According to Brown (2009, p.14) individuals may learn best through listening or reading, they may learn more easily alone or within a small group, they may require heavy visual reinforcement or learn better through verbal explanations, or they may respond better to a sequential or to a random organization of materials or experiences . However, when the teacher used storytelling, the students looked different, they were more enthusiastic and happy. It is line with Rose and Nicholl (1997), "the vivid images stimulated by storytelling promote character identification thus engaging the student as an active participant in the learning process".

\section{b. The Strength and Weaknesses of Teaching Vocabulary Mastery through Storytelling Using Finger Puppet}

From the result of observation and above, it was found that the strength of the use of storytelling using puppet that it is beneficial way to teach vocabulary. 
Because, this method makes the students' interest, and are not easy to get bored at teaching learning process. As Piaget stated in Cameron $(2001$, p.2) the child is seen as continually interacting with the world around her/him, solving problems that are presented by the environment. So they feel more eager while studying, because they do not continue to have to read books to learn, just stay listening to see puppet that some children at age step of elementary school are still interested to play with dolls.

While the weaknesses of the use of storytelling by using puppet as a media in teaching vocabulary is students tend to be more focus on the puppet than the story. Based on Harmer (2008, p. 82) young learners are interested in the meaning and function of new language more holistically, in order to play a game, sing a song or act out a story, and also young learners are generally display an enthusiasm for learning and a curiosity about the world around them. It is because children who are still at elementary school are still more interested in toys, so while telling the story, their focus is slightly divided on the puppet than the story delivered.

\section{c. Students' Response to the Teaching of Vocabulary through Storytelling}

The researcher found the students' response using two instrument, observation and questionnaire. From the observation we can conclude that the students are enthusiastic and happy when the teacher conveyed the material in teaching English especially teaching vocabulary through storytelling using finger puppet. It's because they are interested in the media that the teacher used. And the result from the questionnaire is almost all students love and enjoy learning vocabulary using storytelling, some children argue that using storytelling makes them less bored while studying because they use the media they love, making them more enthusiastic about learning, easily gaining new vocabulary, and making them more quickly understand the meaning of the English language itself. but one of the children thinks that he feels dizzy and does not understand because the story is delivered using English. 


\section{CONCLUSION}

\section{a. Conclusion}

Here are the conclusions of this current study:

1. This research aimed to get insight on the implementation of storytelling by using finger puppet in teaching vocabulary to young learner. After the research was done, the researcher found that there are two steps of the implementation in teaching vocabulary through storytelling, that are:

\section{a. Preparations}

There are some preparations to be provided before teaching vocabulary through storytelling using finger puppet. Among them is the teacher should choose the content of the story before conveyed to the students, the story should be conformed with the age and with the theme of the lesson to be delivered on that day, then the teacher also should prepared the puppet in accordance with the theme of the story will be delivered. Such as, the theme of the story will be submitted to the beast of the animal then the selected animal must also be animal. b. Stages

Teachers should prepare the learning step, such as what activities will be done during the learning process takes place. The learning process consists of three steps, namely pre-activites, while-activities, and post-activities. Therefore, the teachers should really prepare the activities that will be done during the learning process, so that the learning process can take place properly.

2. For the second issues regarding the strength and weaknesses the researcher found them from observation and interview, it shows that:

a. The strenght of storytelling in teaching vocabulary is it increases students' interest in learning English, to make students not easily to get bored while doing the learning, students feel happy while doing the learning process, students tend to understand more quickly and understand about the story that was delivered by the teacher, so this way can help students to easily get a new vocabulary

b. The weaknesses the researcher found that the children become more interested in the puppet than the story, then there are some children who argue they do not 
focus on the whole story but only focus on the dialogue only, and some argue that puppet used is more suitable for female students only

3. For the third issues, this about the student respons the data from questionnaire, it shows that:

Almost all students love and enjoy learning vocabulary using storytelling, some children argue that using storytelling makes them less bored while studying because they use the media they love, making them more enthusiastic about learning English, easily gaining new vocabulary, and making them more quickly understand the meaning of the English language itself. And then they are stated storytelling can make them get new vocabulary easily because the story that the teacher conveys becomes clear because it uses two languages namely English and Indonesian language.

\section{Suggestions}

Based on the conclusion above explained, some suggestions could be directed toward some related parties.

\section{To the Teachers of Jamaras Elementary school}

One of the factors that make the students lack of motivation to learn is because of the difficulty of students to be able to focus on learning because the atmosphere of the class is quite shabby and students from other classes easily enter the class that is during the learning process due to building factors that are inadequate. Such as benches and less decent tables. The lack of motivation of students in learning foreign language lessons is caused by existence of mindset that the English lesson is difficult. The researcher suggest that schools provide more adequate school and class facilities, so that at the learning process students will be more focused. Therefore, it can eliminate their mindset about learning English is difficult and foster confidence among them to learn and even master the English language.

\section{To the Students of Jamaras Elementary School}


Some of many factors determining the success of learning process, are running expected is students' motivation and students' interest. Students seem not interest and do not respond when the teachers speak or just greet with basic English. Because at first they did not know about English vocabulary and lack of confidence in them, so when they speak, they feel afraid of using English. And before the observation they always feel bored quickly while the English lesson, because in addition to the lack of media that makes them less interested to learn, they were also lazy to learn something they did not understand before.

\section{REFERENCES}

Alwasilah,

A. Chaedar.

(2009).

KualitatifDasar-

DasarMerancangPenelitianKualitatif.Jakarta : PT. DuniaPustaka Jaya.

Brown (2009),Young Learners Characteristics, Cambridge: Cambridge University Press.

Bogdan, Robert and Taylor Steven.J. (1975). Introduction to Qualitative Research

Methods.USA : A Wiley-Interscience Publication

Brumfit (1997) Young Learners Characteristics (TEYL/TMYL). (online) (http://peni.staff.uns.ac.id/2008/10/10/young-learner-characteristics/ accessed on

March 9, 2014).

Cameron, Lynne. (2003). Teaching Language to Young Learners. The United Kingdom.Cambridge University Press.

Cameron, L. (2001). Teaching Language to Young Learners, (Press. Cambridge),

Cambridge University

Coady, J. (1997). L2 vocabulary acquisition: A synthesis of the research. Dalam J.

Coady\& T. Huckin (Eds.), Second language vocabulary acquisition (pp. 273-290). New

York: Cambridge University Press.

Cresswell J, W. (1998).Qualitative Inquiry And Research Design. United States of America Sage Publication, Inc.

Eck. Jill (2006).An analysis of Effectiveness Storytelling of Adult Learner in Supervisory Management.An analysis of Storytelling.University of Wisconsin-Stout. P.11

Fraenkel Jack R,.Wallen, E. dan Hyun, H. (2012). How to design and evaluate Research in Education. New York: the McGraw-Hill.

Garland,C. (2013). Using Puppets for Teaching.Retrieved: July 12, 2018. From: https://www.little-linguist.co.uk)

Hornby, A.S. (2005). Oxford Advanced Leamer's Dictionary. Seventh Edition. Oxford. Oxford University Press.

Hatch, E., \& Brown, C. (1995). Vocabulary, Semantics, and Language Education. New

York: Cambridge University Pres 
Harmer, G. (2008).The Practice of English Language Teaching.England : Pearson Longman.

Jackson, A. W., \& Davis, G. A. (2000). Turning Points 2000: Educating adolescents in the 21st century. New York, NY \& Westerville, OH: Teachers College Press \& National Middle School Association.

Jackson Howard Grammar and vocabulary (London and New York,2002), p.28

Lado, R. (2003). Language teaching.A scientific approach. Bombay-New Delhi: Tata McGraw-Hill PublshingCo.LTD

Lewis, R. (1997). Human Genetic Concepts and Application.Second Edition. WEB, USA: 189-191.

Lepley, A.N. (2001). How Puppetry Helps the Oral Language Development of Language

Minority Kindergartners. A Research.Glen Forest Elementary.Fairfax County

Public Schools.

Marshall, C. \&Rossman, G. B. (2006).Designing Qualitative Research.(4th Ed.). Thousand Oaks, CA: Sage.

Moeslichatoen, 1999.Metode Pengajaran. Jakarta: PT. RinekaCipta.

Morgan, S. \&Dennehy, R., (1 997). The power of organizational storytelling: a management development perspective. Journal of Management Development, 16 (7), Retrieved May 29,2005, from Ebsco Host database.

Nation, P., \&Waring, R. (1997). Vocabulary size, text coverage and word lists. In N.

Schmitt, \& M. McCarthy (Eds.), Vocabulary: Description, Acquisition and Pedagogy. Cambridge: Cambridge University Press.

Pellowski, A. 1991.The World of Storytelling. New York: H.W. Wilson.

Pinter, Annamaria. (2006). Teacing Young Language Lerners: An Axxessible Guide to the Theoryand Practice of Teaching English to Children in Primary Education. Oxford: OUP Ocford.

Richards, Jack C and Richard Schmidt. (2002). Longman Dictionary of Language Teaching and Applied Linguistics, 3rd Ed., London: Pearson Education Limited.

Richards, Jack C and Richard Schmidt. (2002). Longman Dictionary of Language Teaching and Applied Linguistics, 3rd Ed., London: Pearson Education Limited.

Rose, C. \& Nichol, M.J. (1997). Accelerated learning for the 21"' century. Dell Publishing: New York.

Setiyadi, Ag. Bambang.(2006). Teaching English as a Foreign Language. Yogyakarta:Grahallmu.

Suyanto, Kasihani K.E. (2007). English for Young Learners. Jakarta: Bumi Aksara.

Yellen, Blake and DeVries. (2004). Developing Speaking Skill. Notes from Integrating the Language Arts, 3rd Ed. Holcomb Hathaway Publishers, Scottsdale. New Zealand. 